九州大学学術情報リポジトリ

Kyushu University Institutional Repository

\title{
A Historical Change of the Regulatory Framework for Non Timber Forest Products in Laos
}

\section{VATTHANATHAM, Southida}

Former Laboratory of Tropical Crops and Environment, Graduate School of Bioresource and Bioenvironmental Sciences, Faculty of Agriculture, Kyushu University | Ministry of Natural Resource and Environment | Institute of Tropical Agriculture, Kyushu University

HYAKUMURA, K.

Institute of Tropical Agriculture, Kyushu University

ONDA, N.

Institute of Decision Science for a Sustainable Society, Kyushu University | Institute of Tropical Agriculture, Kyushu University

OGATA, K.

Institute of Tropical Agriculture, Kyushu University

https://doi.org/10.5109/1955663

出版情報：九州大学大学院農学研究院紀要. 63 (2)，pp.411-416，2018-09-01. Faculty of Agriculture, Kyushu University

バージョン :

権利関係 : 


\title{
A Historical Change of the Regulatory Framework for Non Timber Forest Products in Laos
}

\author{
Institute of Tropical Agriculture, Kyushu University \\ (Received April 24, 2018 and accepted May 8, 2018)
}

Southida VATTHANATHAM ${ }^{1,4}$, K. HYAKUMURA ${ }^{2 *}$, N. ONDA $^{3}$ and K. OGATA ${ }^{2}$

\begin{abstract}
The Lao People's Democratic Republic (Laos) is economically a Least Developed Country in Southeast Asia and characterized by rich natural resources and biodiversity. A majority of the rural population relies on natural resources, particularly non timber forest products (NTFPs). NTFPs contribute significantly to rural livelihoods for both subsistence and cash incomes. They not only support the well-being and food security of local communities, but also contribute to national revenues. Thus, the demand for NTFPs from both local communities and the business sectors is very high. However, harvests of some commercial NTFPs species have decreased due to overharvesting. Many NTFP policies have been developed over the course of four decades, but there has been little analysis of the stages of government attempts to manage these resources. The objectives of this study are to identify the characteristics of the regulatory framework that has evolved for NTFPs in Laos over the past four decades, and to understand how the government has attempted to manage their use by local communities and the business sector. This study involved an extensive literature review of NTFP-related policies and relevant documents. It found that the development of NTFP policies in Laos can be divided into four periods, with the third period (1996 to 2006) being the most important one for the creation of many aspects of the regulatory framework, including legislation on NTFP utilization rights and village forest rights. During the fourth period, the government also tried to control commercial use of NTFPs by imposing obligations on the business sector and conserving the most valuable NTFPs. The study concludes that the current regulatory framework has the potential to secure NTFP resources, although as it is currently being implemented, illegal harvesting of NTFPs still occurs. Therefore, further improvements are still needed in the implementation of the NTFP regulatory framework.
\end{abstract}

Key words: Business sector, Laos, local people, non-timber forest products, regulatory framework

\section{INTRODUCTION}

With forests covering more than $40 \%$ of the total land area, the Lao People's Democratic Republic (Laos) in Southeast Asia is characterized by rich natural resources and biodiversity (MONRE, 2016). It is classified as a Least Developed Country (UNCTAD, 2017) and home to approximately 6.8 million people, with around 60-70\% living in rural areas (World Bank, 2016). Most of the rural population relies on natural resources for a living, particularly non timber forest products (NTFPs) (Foppes and Ketphanh, 2004). NTFPs are a direct part of daily life for local people (Clendon, 2001). The subsistence use of NTFPs plays a much larger role than cash income in the family economy of the rural population and is a key coping mechanism for the poorest families (Foppes and Ketphanh, 2004). Although timber extracted from forests in Laos for sale amounts to around 0.3-0.45 million $\mathrm{m}^{3} / \mathrm{year}$, fuel wood as an NTFP for local use amounts to around 7.1 million $\mathrm{m}^{3} /$ year (Hyakumura, 2009). In other words, the demand for fuel wood is 20 times that of timber. The total value of NTFPs for all rural household consumption in Laos was estimated at about 224 million US dollars as of 2009 (ibid.). Rural

\footnotetext{
1 Former Laboratory of Tropical Crops and Environment, Graduate School of Bioresource and Bioenvironmental Sciences, Faculty of Agriculture, Kyushu University Institute of Tropical Agriculture, Kyushu University

Institute of Decision Science for a Sustainable Society, Kyushu University

${ }^{4}$ Ministry of Natural Resource and Environment, Lao PDR

* Corresponding author (E-mail: hyaku@agr.kyushu-u.ac.jp)
}

populations in Laos depend on NTFPs not only for subsistence use but also for cash income (Clendon, 2001). Almost half of cash income generation of rural populations came from NTFPs; for instance, $49 \%$ in Luangprabang Province (Yokoyama 2003) and 41\% in Khammuane Province (Hyakumura, 2009). The commercial use of NTFPs is thus seen as one way to "lift people out of poverty" (Angelsen and Wunder, 2003). Moreover, NTFPs can provide not only local community benefits, but also contribute to the national economy, at about $9.2 \%$ of GDP in 2009, equivalent to around 510 million US dollars (ICEM, 2014). However, the output of some commercial NTFP species, such as cardamom (Hkum et al., 2005), orchids (CITES, 2008; Orchidees, 2009), columbo wood, tiger grass, malva nuts (Phounvisouk, 2013), and benzoin (NAFRI, 2016), have decreased due to overharvesting and illegal harvesting. Since the establishment of Laos as a country, the government has attempted to conserve forests by developing policies and regulatory frameworks relating to forest resources, including NTFPs. Research has already been carried out on several topics relating to NTFPs in Laos, including the importance of NTFP utilization for local people (Vongkhamsao, 2006; Kasper and Thomas, 2004; Baird and Bounphasy, 2003), NTFP marketing (Phounvisouk, 2013; Nicholson et al., 2008; Sophatilath et al., 2006; Soydara and Ketphanh, 2000), and NTFP value chains (Choulatida and Ngeuamboubpha, 2012; EDC, 2009; Jasen, 2009; Greijmans et al., 2007). In order to conserve NTFP resources sustainably, the government has developed several policies and regulatory frameworks for NTFP management, but little analysis has been 
done about how the government has tried to manage NTFP resources for local people and the business sector. Therefore, the objectives of this study are to (1) identify the characteristics of NTFP-related regulatory frameworks in Laos from the establishment of Laos as a country until present, and to (2) understand how the government has attempted to manage the utilization of NTFPs by both local people and the business sector.

This study involved an extensive literature review of NTFP policies in Laos and relevant documents covering the period 1975 to 2016. It identifies trends in NTFPrelated policies under different socioeconomic conditions, and clarifies historical changes in rights and obligations relating to NTFP use by local people and the business sector. The study ends with a concluding discussion about how the government has tried to manage NTFP resources.

\section{RESULTS AND DISCUSSIONS}

\section{Trends of NTFP policies and socioeconomic condi- tions}

Trends of NTFP policies and socioeconomic conditions

In the more than 40 years since Laos was established as a country in 1975, it has adopted 73 forest-related regulatory tools, including prime ministerial decrees, laws and their revisions, ministerial orders, ministerial regulations, and notifications. Among them, 16 regulatory tools were directly linked with the management of NTFPs. Trends in NTFP-related regulatory tools can be divided into four periods-Period I (1975-1992), Period II (1993-1995), Period III (1996-2006), and Period IV (2007-2016) - based on the governments objectives, national conditions, and the state of forest resources management under the Lao government (Table 1). During Period I, some forest-related regulatory tools were developed, but they were not linked directly with NTFP management. Mostly local people used NTFPs for subsistence income. During Period II, the government established a fundamental regulatory framework and created categories of forest types, while a market economy evolved to include NTFPs. During Period III, Lao policy shifted from the fundamental stage to the enforcement stage, while the market for NTFPs boomed. Eleven out of 16 regulatory tools were developed during Period III. In Period $\mathrm{IV}$, the government attempted to control NTFP harvesting, as a response to overharvesting. Lao economic conditions expanded significantly during this period, and both local people and the business sector increased their commercial uses of NTFPs. In response, the government attempted to develop many regulatory tools for promoting and controlling NTFP usage. As a whole, Period III could be seen as the key period in terms of NTFP policy development.

\section{Historical changes in NTFP usage rights for local people and the business sector \\ Local livelihoods and rights}

Based on four different periods of NTFPs related policies, the rights of local people to use NTFPs under the forest regulatory framework can be described as shown below (Table 2). In Period I, there was no regulatory framework relating specifically to NTFPs after the establishment of Laos. During this period, local people could harvest NTFPs without any restrictions, in any forest area. In Period II, Prime Ministerial Decree No. 169 (169/PM) created the fundamental national regulatory framework for forest management. This decree designated five forest categories in terms of function and existing forest condition: protection forest, production forest, conservation forest, regenerated forest, and degraded forest. The decree stated that local people have the right to harvest forest resources including NTFPs in all types of forest for traditional use. However, the decree did not mention any commercial use. The government developed regulations regarding conservation forests at the national level under Prime Ministerial Decree No.

Table 1. Trends in NTFP policies and socioeconomic conditions

\begin{tabular}{|c|c|c|c|c|}
\hline Period & I (1975-1992) & II (1993-1995) & III (1996-2006) & IV (2007-2016) \\
\hline Policy development & $\begin{array}{c}\text { Some forest regulatory } \\
\text { tools developed (no } \\
\text { NTFPs) }\end{array}$ & $\begin{array}{l}\text { Fundamental regulatory } \\
\text { framework established, } \\
\text { forest types categorized } \\
\text { (fundamental stage) }\end{array}$ & $\begin{array}{c}\text { Shift to enforcement } \\
\text { stage }\end{array}$ & $\begin{array}{l}\text { More control of } \\
\text { commercial uses }\end{array}$ \\
\hline $\begin{array}{c}\text { Regulatory tools } \\
\text { created: NTFP-related } \\
\text { (16 total) }\end{array}$ & 0 & 2 & 11 & 3 \\
\hline $\begin{array}{c}\text { Regulatory tools } \\
\text { created: forest-related } \\
\text { (73 total, including } 16 \\
\text { for NTFPs) }\end{array}$ & 8 & 6 & 38 & 22 \\
\hline Government objectives & $\begin{array}{l}\text { Transition to market } \\
\text { economy }\end{array}$ & $\begin{array}{l}\text { Transition to market } \\
\text { economy }\end{array}$ & $\begin{array}{c}\text { Promote \& control NTFP } \\
\text { harvesting }\end{array}$ & $\begin{array}{c}\text { Maintain promotion \& } \\
\text { control }\end{array}$ \\
\hline $\begin{array}{l}\text { Socioeconomic } \\
\text { conditions }\end{array}$ & $\begin{array}{l}\text { NTFPs mostly for } \\
\text { subsistence income }\end{array}$ & $\begin{array}{l}\text { Commercial sellling of } \\
\text { NTFPs begins }\end{array}$ & $\begin{array}{c}\text { NTFP } \\
\text { marketing booms }\end{array}$ & NTFP marketing declines \\
\hline
\end{tabular}


164 (164/PM). Under this decree, local people are not allowed to harvest forest resources, including NTFPs, in core zones and corridor zones, intended to protect specified flora and fauna. On the other hand, in a utilization zone, local people are allowed to use NTFPs for traditional use. In Period III, the Forestry Law was issued to replace 169/PM. In terms of NTFP management, this law designated two types of forest use for NTFPs and forest resources: traditional use and commercial use. Local people have been officially allowed to earn income from NTFPs since this period. With Period IV, the control stage for commercial-purpose NTFPs began. The revised Forestry Law, enacted in 2007, re-classified forests from five to just three types in terms of management objectives: protection forest, production forest, and conservation forest. For traditional use, local people can continuously collect NTFPs in all types of forest except in core zones and corridor zones of conservation forests. For commercial use, local people can collect NTFPs only in protection forests and production forests. For commercial use, local people lose the right to collect NTFPs in the utilization zone of conservation forests. This means that local people who rely on conservation forests may lost the official right to sell NTFPs. In 2015, Decree 134/ PM on conservation forests replaced Decree 164/PM. Under this revised decree, conservation forests are designated at four levels, from national to the village level, and at the national level they are newly divided into four zones: protection, controlled use, corridor, and buffer. The controlled-use zone of conservation forests has the same function as the utilization zone in the previous decree. Under this new classification, local people can continuously collect NTFPs in the controlled-use zone for traditional use.

Table 2. Historical changes in NTFP usage rights for local people in Laos

\begin{tabular}{|c|c|c|c|c|c|c|c|c|c|c|}
\hline \multirow{3}{*}{ Year Period } & \multirow{3}{*}{ Regulatory } & \multirow{3}{*}{ Rights of use } & \multicolumn{8}{|c|}{ Forest categories } \\
\hline & & & \multirow{2}{*}{ Protection } & \multirow{2}{*}{ Production } & \multicolumn{4}{|c|}{ Conservation } & \multirow{2}{*}{ Regenerated } & \multirow[t]{2}{*}{ Degraded } \\
\hline & & & & & Cor & & Corridor & Utilization & & \\
\hline $\begin{array}{l}1975-92 \\
\text { Period I }\end{array}$ & $\begin{array}{l}\text { No NTFP regula- } \\
\text { tory framework }\end{array}$ & Free Access & & & & & $\bigcirc$ & & & \\
\hline \multirow{2}{*}{$\begin{array}{l}1993 \\
\text { Period II }\end{array}$} & \multirow{2}{*}{$\begin{array}{l}\text { Decree 169/PM } \\
\text { Decree 164/PM }\end{array}$} & Traditional use & 0 & 0 & \multicolumn{2}{|c|}{$x$} & $x$ & 0 & 0 & 0 \\
\hline & & Commercial use & $?$ & $?$ & \multicolumn{2}{|c|}{$?$} & $?$ & $?$ & $?$ & $?$ \\
\hline \multirow{2}{*}{$\begin{array}{l}1996 \\
\text { Period III }\end{array}$} & \multirow[t]{2}{*}{ Forestry Law } & Traditional use & 0 & 0 & \multicolumn{2}{|c|}{$x$} & $\times$ & 0 & 0 & 0 \\
\hline & & Commercial use & 0 & 0 & \multicolumn{2}{|c|}{$x$} & $x$ & $x$ & 0 & 0 \\
\hline \multirow{2}{*}{$\begin{array}{l}2007 \\
\text { Period IV }\end{array}$} & \multirow{2}{*}{$\begin{array}{l}\text { Forestry Law } \\
\text { (Revised) }\end{array}$} & Traditional use & 0 & 0 & \multicolumn{2}{|c|}{$x$} & $x$ & 0 & & \\
\hline & & Commercial use & 0 & 0 & \multicolumn{2}{|l|}{$x$} & $x$ & $\times$ & & \\
\hline \multirow[t]{3}{*}{$\begin{array}{l}2015 \\
\text { Period IV }\end{array}$} & \multirow[t]{3}{*}{$\begin{array}{l}\text { Decree } \\
\text { 134/PM }\end{array}$} & & Production & Protection & \multicolumn{2}{|l|}{ 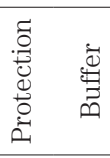 } & 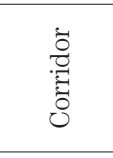 & 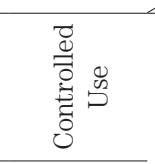 & & \\
\hline & & Traditional & 0 & 0 & $x$ & $x$ & $x$ & 0 & & \\
\hline & & Commercial & 0 & 0 & $x$ & $x$ & $x$ & $x$ & & \\
\hline
\end{tabular}

O: Permitted, $\times$ : Prohibited, ?: Not stated

Table 3. Historical changes in NTFP usage rights for the business sector

\begin{tabular}{|c|c|c|c|c|c|c|c|c|c|c|}
\hline \multirow{3}{*}{$\begin{array}{l}\text { Year and } \\
\text { Period }\end{array}$} & \multirow{3}{*}{ Regulatory } & \multirow{3}{*}{ Rights of use } & \multicolumn{8}{|c|}{ Forest categories } \\
\hline & & & \multirow{2}{*}{ Protection } & \multirow{2}{*}{ Production } & \multicolumn{4}{|c|}{ Conservation } & \multirow[t]{2}{*}{ Regenerated } & \multirow[t]{2}{*}{ Degraded } \\
\hline & & & & & \multicolumn{2}{|c|}{ Core } & Corridor & Utilization & & \\
\hline $\begin{array}{l}(1975-1992) \\
\text { Period I }\end{array}$ & $\begin{array}{l}\text { No NTFP regula- } \\
\text { tory framework }\end{array}$ & Free Access & & & & & $\bigcirc$ & & & \\
\hline $\begin{array}{l}1993 \\
\text { Period II }\end{array}$ & $\begin{array}{l}\text { Decree169/PM } \\
\text { Decree164/PM }\end{array}$ & $\begin{array}{l}\text { Harvesting } \\
\text { on NTFP }\end{array}$ & O & $\bigcirc$ & $\times$ & & $\times$ & $\times$ & $\bigcirc$ & O \\
\hline $\begin{array}{l}1996 \\
\text { Period III }\end{array}$ & Forestry Law & $\begin{array}{l}\text { Harvesting } \\
\text { on NTFP }\end{array}$ & $\times$ & O & $\times$ & & $\times$ & $\times$ & $\bigcirc$ & O \\
\hline $\begin{array}{l}2007 \\
\text { Period IV }\end{array}$ & $\begin{array}{l}\text { Revised Forestry } \\
\text { Law }\end{array}$ & $\begin{array}{l}\text { Harvesting } \\
\text { on NTFP }\end{array}$ & $\times$ & 0 & $\times$ & & $x$ & $x$ & & \\
\hline $\begin{array}{l}2015 \\
\text { Period IV }\end{array}$ & $\begin{array}{l}\text { Decree } \\
134 / \mathrm{PM}\end{array}$ & & Protection & Production & 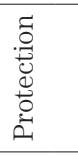 & 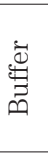 & 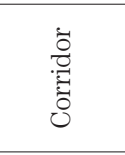 & 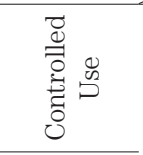 & & \\
\hline & & & $\times$ & 0 & $\times$ & $\times$ & $x$ & $\times$ & & \\
\hline
\end{tabular}

: Permitted, $\times$ : Prohibited, ?: Not stated 
NTFP harvesting rights for the business sector

Table 3 describes NTFP harvesting rights for the business sector under the forest regulatory framework of Laos, based on the four different periods for NTFPrelated policies. In Period I, there was no regulatory framework on NTFPs. In the absence of any regulatory system, all business sectors were able to use NTFPs from forests commercially. In Period II, a forest regulatory framework including NTFPs was developed under decrees 169/PM and 164/PM, which stated that all business sectors were allowed to harvest NTFPs in all types of forests except conservation forests. In Period III, under the Forestry Law, the collection of NTFPs for commercial purposes was prohibited in protection forests and conservation forests. In Period IV, the government has been trying to control business sector use of NTFPs and other forest resources, and allows the business sector to harvest NTFPs only in production forests.

Table 4 summarizes the historical changes in NTFPrelated rights for local people and the business sector. In the period after the establishment of Laos as a country (Period I), both local people and the business sector had free access to harvest NTFPs in the absence of any regulatory framework. With the development of the forest regulatory framework (Period II), local people were allowed traditional uses of NTFPs while the business sector also had commercial rights to use NTFPs in all types of forest except conservation forests. When the enforcement stage of forest-related policies began in Laos (Period III), the government started to control commercial use of NTFPs. The collection of NTFPs in con- servation forests for commercial is prohibited not only for the business sector, but also for local people. In addition, NTFP collection in protection forests is prohibited for the business sector.

\section{NTFP rights in village forests}

The concept of the "village forest" developed after the enactment of the Forestry Law in 1996. From this, local people could obtain the right to use the forest in their own territories as "village forests." According to Order 377/MAF, Order 54/MAF and the Forestry Law, local people are required to follow village forestry regulations, which prohibit actions causing damage to village forests. The forest-related regulatory tools called upon local people to use NTFPs in sustainable way in their forest areas. During period III, Regulation No. 524/MAF stated that local people could not collect commercial NTFPs in a village forest if it overlapped with a conservation forest. Since full market controls were implemented in Period IV, the government has tried to control harvesting methods of NTFPs to ensure that they are done in a sustainable way for local people under the revised Forestry Law. Table 5 provides a summary of NTFP rights in village forests.

\section{Obligations of commercial NTFPs}

The government considered commercial uses of NTFPs for local people and the business sector since legislation permitted forest use for the market economy starting in Period III. In this context, forest-related regulatory tools have different effects for local people and

Table 4. Summary of historical changes in NTFP usage rights for local people and the business sector

\begin{tabular}{|c|c|c|c|c|}
\hline Period & I (1975-1992) & II (1993-1995) & III (1996-2006) & IV (2007-2016) \\
\hline Local people & Free access & $\begin{array}{l}\text { - Traditional use }(\bigcirc) \text { (except in } \\
\text { core zone of conservation forest) } \\
\text { - Commercial use (?) }\end{array}$ & $\begin{array}{l}\text { - Traditional use }(\bigcirc) \text { (except in } \\
\text { core zone of conservation forest) } \\
\text { - Commercial use }(\bigcirc) \text { (except in } \\
\text { conservation forest) }\end{array}$ & $\Rightarrow$ Same as period III \\
\hline Business sector & Free access & $\begin{array}{l}\text { - Commercial use }(\bigcirc) \text { (except in } \\
\text { conservation forest) }\end{array}$ & $\begin{array}{l}\text { - Commercial use }(\bigcirc) \text { (except in } \\
\text { conservation and protection } \\
\text { forest) }\end{array}$ & $\Rightarrow$ Same as period III \\
\hline NTFP policy trend & $\begin{array}{l}\text { No NTFP } \\
\text { regulatory } \\
\text { framework }\end{array}$ & $\begin{array}{l}\text { - Secure local traditional rights } \\
\text { - Open marketing } \\
\text { - Conserve conservation forests }\end{array}$ & $\begin{array}{l}\text { - Provide local commercial rights } \\
\text { - Conserve protection forests }\end{array}$ & No change \\
\hline
\end{tabular}

Table 5. NTFP rights in village forests

\begin{tabular}{|c|c|c|}
\hline Year and Period & Regulatory framework & Village Forest Regulation \\
\hline 1996 (III) & $\begin{array}{l}\text { - Forestry Law } \\
\text { - Order 54/MAF } \\
\text { - Order 377/MAF }\end{array}$ & $\begin{array}{l}\text { - Concept of "village forest" developed } \\
\text { - Local people have right to use village forests } \\
\text { - Sustainable use of NTFPs required in village forests }\end{array}$ \\
\hline 2001 (III) & - Regulation No.524/MAF & $\begin{array}{l}\text { - Commercial NTFPs cannot be collected in conservation forests that overlap with village } \\
\text { forests }\end{array}$ \\
\hline 2007 (IV) & • Revised Forestry Law & $\begin{array}{l}\text { - Techniques and training are required for harvesting NTFPs for commercial use, reducing } \\
\text { negative impacts for village forests. }\end{array}$ \\
\hline
\end{tabular}


the business sector. Since the business sector utilizes a large number of NTFPs, the government needs to impose obligations for the conservation of NTFP resources. Three forest-related regulatory tools (Order 1848/MAF, Order 10/PM and Order 111/MOF) stated that commercial harvesting of NTFPs by the business sector should involve a bidding system for permits. The winner of a bid is required to pay a tax to the relevant District of Finance Office. On the other hand, local people are not required to pay any tax on NTFPs, even for commercial uses. In terms of commercial NTFP use, only the business sector is required to follow several obligations such as paying a tax and participating in bidding for harvesting rights (Table 6).

\section{Exporting NTFPs}

For exporting NTPFs, the government tried to regulate NTFP use through several regulatory tools. Order 10/PM, 2000 and Order 15/PM, 2001 stated that three valuable NTFP species (eaglewood, sandalwood and rattan) are not allowed to be exported as raw material. If these NTFPs were to be sold unprocessed as raw material, the economic benefits on the Laos side would be quite limited due to low selling prices. Thus, the government sought more national revenue from these NTFP species. In 2003, Decree 155/PM prohibited the export of medicinal NTFPs, in order to secure the nation's genetic resources. Only local people are permitted to collect and use them, for traditional uses. In 2016, Notification 1355/ PM stated that for the commercial export of NTFPs, all business sectors must comply with restrictions. NTFPs that can be processed in Laos into semi-final or final products, such as rattan, bamboo, cardamom and medicinal plants, cannot be exported as raw materials. The regulations also prohibited the export of black charcoal. While opening up the market in Period III, the government also tried to maximize national revenues from NTFPs and to protect genetic resources of medicinal spe- cies (Table 7).

\section{Final Discussion}

Over the course of four decades, the government of Laos has developed a regulatory framework for NTFPs with the aim of both controlling and promoting the use of NTFPs, particularly in Period III (1996-2006). Since opening up the market, the government has tried to manage the use of NTFPs sustainably and at the same time ensure national benefits. For local people, the government has made an effort to secure local rights for traditional uses and to ensure that forest use is sustainable. On the other hand, the government has made an effort to control the business sector, by using permissions and obligations. In terms of conservation, the government has attempted to maximize value-added revenues from NTFPs as well as secure genetic resources for the national benefit. Under these government intentions, the current regulatory framework has the potential to secure NTFP resources. Nevertheless, even with the implementation of the existing regulatory framework, illegal trading is still observed (Hkum et al., 2005; CITES, 2008; Orchidees, 2009; Phounvisouk, 2013; NAFRI, 2016). Thus, there is still room for improvements in implementation of the regulatory framework for NTFPs.

\section{CONCLUSIONS}

The regulatory framework for NTFPs in Laos has evolved over the course of four decades. The government has made significant efforts to both promote and control the use of NTFPs by rural communities and the business sector in order to contribute to poverty eradication and national development. Some weaknesses still remain, however. In order to improve the management and conservation of NTFP resources and reduce illegal behavior, some improvements are needed in the implementation of the regulatory framework.

Table 6. Obligations for commercial NTFPs

\begin{tabular}{llll}
\hline \multicolumn{1}{c}{ Year } & \multicolumn{1}{c}{ Regulatory } & \multicolumn{1}{c}{ Contents } & Business sector \\
\hline \multirow{2}{*}{2000 (III) } & $\begin{array}{l}\text { - Order 10/PM } \\
\text { • Order 111/MAF }\end{array}$ & $\begin{array}{l}\text { Payment of harvest tax for commercial } \\
\text { NTFPs }\end{array}$ & Yes \\
\hline \multirow{2}{*}{2004 (III) } & $\bullet$ Instruction 2297/MAF & $\begin{array}{l}\text { Introduction of bidding system for } \\
\text { commercial NTFPs }\end{array}$ & Yes \\
\hline
\end{tabular}

Table 7. Exporting NTFPs

\begin{tabular}{|c|c|c|c|}
\hline Year & Regulatory & NTFP Species & Contents \\
\hline 2000 (III) & - Order 10/PM & & Export of NTFPs requires government permission \\
\hline $\begin{array}{l}2000 \\
2001 \text { (III) }\end{array}$ & $\begin{array}{l}\text { - Order 10/PM } \\
\text { - Order 15/PM }\end{array}$ & Eaglewood, sandalwood, rattan & Export of 3 specific NTFPs prohibited \\
\hline 2003 (III) & - Decree 155/PM & All medicinal plants & Export of medicinal plants is prohibited \\
\hline 2016 (IV) & - Notification 1355/ PM & All NTFPs & $\begin{array}{l}\text { NTFPs that can be processed into semi-final or } \\
\text { final products inside Laos cannot be exported as } \\
\text { raw materials. }\end{array}$ \\
\hline
\end{tabular}




\section{AUTHOR CONTRIBUTIONS}

Southida Vattnanatham designed the study, carried out the literature review and wrote a draft of this paper. Kimihiko Hyakumura supervised the work and further developed the paper. Nariaki Onda offered advice on the analysis of historical changes in NTFP policies. Kazuo Ogata was the primary supervisor for the first author and provided supervision and guidance throughout this study. All authors assisted in the editing of the manuscript and approved the final version.

\section{ACKNOWLEDGEMENTS}

This research was supported by JDS/JICA.

\section{REFERENCES}

Angelsen, A. and S. Wunder 2003 Exploring the forest-poverty link: key concepts, issues and research implications. CIFOR, Bogor (Indonesia)

Baird, I. G. and S. Bounphasy 2003 Non timber forest product use, management and tenure in Pathoumphone District, Champasak Province, Southern Laos. Remote village education support project, Global Association for People and the Environment (GAPE), Vientiane (Lao PDR)

Choulatida, P. and S. Ngeuamboubpha 2012 Final draft report bamboo mat value chain. Case study of Vieng Xai District, Houaphanh Province, Lao PDR. GRET and SNV, Vientiane (Lao PDR)

CITES 2008 Convention on International Trade in Endangered Species of Wild Fauna and Flora Statistics. https:// cites.org/eng/disc/species.php (accessed on September 5, 2017)

Clendon, K. 2001 The role of forest food resources in village livelihood systems: A study of three villages in Salavan Province, Lao PDR. IUCN-NTFP Project, Vientiane (Lao PDR)

Enterprise and Development Consultants Co., Ltd. (EDC) 2009 Edible rattan shoot business feasibility study-case study in Bolikhamxay, Savannakhet and Vientiane Capital, Lao PDR. EDC, Vientiane (Lao PDR), pp. 1-45

Foppes, J. and S. Ketphanh 2004 Non-Timber forest products for poverty reduction and shifting cultivation stabilization in uplands of Lao PDR. The NAFRI workshop on poverty reduction and shifting cultivation stabilization in the uplands of Lao PDR: Technologies, approaches and methods for improving upland livelihoods, January 27-30, 2004. NAFRI, Vientiane (Lao PDR), pp. 181-193

Greijmans, M., B. Oudomvilay and J. Benzon 2007 Houaphanh bamboo value chain analysis: Identifying SNV's potential advisory services for the development of the bamboo value chain. The Netherlands Development Organization (SNV). Vientiane (Lao PDR)

Hkum, S., N. Hkum and Maodee 2005 Marketing and domestica- tion of NTFPs in Phongsaly three districts. Paper prepared for the NTFP MIS workshop 5-6 July 2005. Phongsaly Alternative Development Project. Vientiane (Lao PDR)

Hyakumura, K. 2009 Visualization of forest resources in Laos. Presentation material on Nagoya University Global COE International Workshop "Understanding the contemporary environmental matters in mainland Southeast Asia" Nagoya University, December 5, 2009. Nagoya (Japan)

International Centre for Environmental Management (ICEM) 2014 USAID Mekong ARCC climate change impact and adaption study for the Lower Mekong Basin: Non timber forest products and crop wild relatives. ICEM, Vientiane (Lao PDR)

Jasen, A. 2009 Valuation of non-timber forest products value chains. J. For. Pol. and Econ., 11(1): 34-41

Kasper, H. and J. Thomas 2004 Non timber forest products and rural livelihoods: A case study on local management and marketing of non timber forest products in two national protected areas, Savannakhet Province, Lao PDR. Master thesis of The Royal Veterinary and Agricultural University, Copenhagen (Denmark)

Ministry of Natural Resources and Environment of Laos (MONRE) 2016 Fifth national report to the United Nations Convention on Biological Diversity. MONRE, Vientiane (Lao PDR)

National Agriculture and Forestry Research Institute of Laos (NAFRI) 2016 Presentation on the main research finding on development of benzoin (Styrax tonkinensis) value chain in five upland provinces (Houaphanh, Luangprabang, Phongsaly, Oudomxay and Xiengkhouang) of Laos. Policy Think Tank National Agriculture and Forestry Research Institute 31 March 2016. NAFRI, Vientiane (Lao PDR)

Nicholson, K., S. Ketphanh and K. Sengdara 2008 Mission report: Review of experiences in the marketing, production, harvesting and management of agro-biodiversity and NTFPs products. The Agro Biodiversity Initiative, Vientiane (Lao PDR)

Orchidees, V. 2009 Orchid trade study: Laos 2009. Vientiane Orchidees. Vientiane (Lao PDR)

Phounvisouk, L. 2013 Non-timber forest products marketing: trading network of trader and market chain in Luang Namtha Province, Laos. IOSR JHSS., 18(4): 48-57

Sophatilath, P., S. Binayee, T. Ledecq and J. Foppes 2006 Non timber forest products (NTFPS) marketing and communitybased enterprise development. NAFRI, Vientiane (Lao PDR)

Soydara, V., and S. Ketphanh 2000 Case study on the marketing group of bitter bamboo shoots in Nam Pheng Village, Oudomxai Province. NAFRI and IUCN, Vientiane (Lao PDR)

United Nations Conference on Trade and Development (UNCTAD) 2017 List of least development countries 2017. The United Nations Conference on Trade and Development http://unctad. org/en/pages/aldc/ (accessed on 8th Aug. 2017)

Vongkhamsao, V. 2006. The importance, role and value of non wood forest product for Laotian food security, nutrition and livelihoods (final draft). NAFRI, Vientiane (Lao PDR).

World Bank 2016 Population in Laos 2016. http://data.worldbank.org/ (accessed on August 8, 2017)

Yokoyama, S. 2003 A geographical study on the basis for existence of mountainous villages in Northern Laos. PhD diss., University of Tsukuba, Tsukuba (Japan) 